\title{
Andrzej Szczepanek
}

Uniwersytet Jana Kochanowskiego w Kielcach

Wydział Lekarski i Nauk o Zdrowiu

andrzejszczepanek@op.pl

\section{Występowanie pałeczek Legionella sp. w instalacjach ciepłej wody użytkowej w obiektach hotelarskich na terenie województwa świętokrzyskiego}

Artykuł nadesłany: 22 czerwca 2017 r.; artykuł zaakceptowany: 15 grudnia 2017 r.

JEL Classification: I18

Keywords: Legionella sp., hotels, hot water systems, Legionellosis

\begin{abstract}
Legionella sp. contamination in hot water systems in hotels in the Świętokrzyskie Voivodship

Introduction: In the European Union countries there were detected 6933 cases of legionellosis (Legionnaires' disease) in 2014. The disease is caused by Legionella sp. bacteria, which are responsible for Legionella sp. pneumonia infection and common in both natural and artificial water environments. If there is proper temperature and nutrients, the bacteria multiply rapidly in artificial environments (hot water systems, central air conditioning systems, and medical devices), posing a risk to human health.
\end{abstract}

Aims: This study was conducted to quantify the frequency of contamination with Legionella sp. of hot water systems in some hotels in the Świętokrzyskie Voivodeship.

Materials and methods: 228 buildings (103 hotels and 125 other types of lodging) were investigated in the years 2009-2015, 1414 samples were collected which were later analyzed by membrane filtration technique in the laboratories of the State Sanitary Inspection in the Świętokrzyskie Voivodeship, conforming to the methods of PN-ISO 11731-2:2008.

Results: Legionella $s p$. was detected in $30.3 \%$ of the hot water systems investigated. The problem of bacteria colonization was more frequent in the hotel buildings $(41.2 \%)$ that in other types of lodging (20.8\%). In 34 hotels and 20 other buildings the level of contamination was medium (Legionella sp. 100-1000 CFU/100 ml sample), and in 9 hotel and 6 other buildings the contamination was high (Legionella sp. 1000-10000 CFU/100 ml sample). In general out of 1414 collected samples, medium and high contamination with Legionella sp. was detected in 272 samples $(19.2 \%)$.

Ekonomia — Wroclaw Economic Review 23/4 (2017)

(C) for this edition by CNS 
Conclusions: The results obtained in the study confirm an overall presence of Legionella sp. in hot water systems of hotels and other lodgings in the Świętokrzyskie Voivodeship. Having analyzed the data from the years 2009-2015, there may be observed a slight decline in the frequency of contamination in the recent years. Nonetheless, it is alarming that despite a periodic control system at some of the locations, the level of contamination is still significant.

\section{Wstęp}

Osoby korzystające z obiektów hotelowych oczekują wysokiej jakości świadczonych usług w przystępnej cenie. O wysokiej jakości możemy mówić tylko wtedy, gdy korzystanie z usług noclegowych nie niesie z sobą zagrożenia dla zdrowia i życia osób przebywających w obiektach hotelowych. Źle zaprojektowana, wykonana lub eksploatowana instalacja wodociągowa budynków może stanowić źródło narażenia na bakterie z rodziny Legionellaceae, w szczególności na gatunek Legionella pneumophila, wywołujący $80-90 \%$ rozpoznanych przypadków legionellozy (Fields 2002, s. 507).

Do identyfikacji bakterii Legionella pneumophila doprowadziła tajemnicza epidemia, która wybuchła w lipcu 1976 roku. Dotknęła ona uczestników Konwentu Legionu Amerykańskiego odbywającego się w hotelu Bellevue-Stratford w Filadelfii. Spośród 3500 uczestników 221 osób zachorowało na „tajemniczą chorobę" o objawach przypominających ciężką postać zapalenia płuc. Śmiertelność wynosiła około 16\% (zmarło 36 osób). W 2014 roku w krajach Unii Europejskiej zanotowano 6933 przypadki zachorowań na legionellozowe zapalenie płuc, z czego 1070 przypadków u osób podróżujących. Odsetek zakażeń pałeczkami Legionella mający związek z podróżą wynosi około 20\% (ECDPC 2016, s. 11).

Do chwili obecnej wyizolowano i opisano co najmniej 52 gatunki oraz 72 serotypy bakterii należące do rodziny Legionellaceae. Za potencjalnie chorobotwórcze uznano wszystkie szczepy Legionella, a w przypadku 18 chorobotwórczość potwierdzono (Palusińska-Szysz, Cendrowska-Pinkosz 2008, s. 346).

Bakterie z rodzaju Legionella powszechnie występują w naturalnych i sztucznych rezerwuarach wodnych. Izolowane są z gruntowych i powierzchniowych wód słodkich, strefy przybrzeżnej wód morskich oraz gleby. Szczególnym zagrożeniem dla zdrowia i życia ludzi stają się w wypadku kolonizacji instalacji wody ciepłej i zimnej budynków, urządzeń klimatyzacyjnych, aparatury medycznej (respiratory, unity stomatologiczne), basenów, chłodni kominowych czy fontann (Stojek 2004, s. 62). W systemach wodnych, w których występuje dostęp do substancji odżywczych oraz sprzyjająca temperatura $\left(25-45^{\circ} \mathrm{C}\right)$, mają one zdolność do szybkiego namnażania się (Krogulska et al. 2014, s. 326). Źródłem zakażenia człowieka jest aerozol wodny oraz woda zawierająca bakterie Legionella. Dotychczas nie odnotowano przypadków przenoszenia się bakterii Legionella pomiędzy ludźmi (WHO 2011, s. 244). Szczególnie niebezpieczne jest wdychanie aerozolu o średnicy kropel 2-5 $\mu \mathrm{m}$, mogącego bezpośrednio osadzać się w pęcherzykach płucnych. Dawka zakaźna nie została jednak dokładnie określona. Zakłada się, iż 
w ilości $10^{3}-10^{5}$ komórek w litrze wody mogą powodować sporadyczne zakażenie drogą inhalacyjną zdrowej osoby (Matuszewska, Krogulska 2009, s. 57).

Legionelloza występuje $w$ trzech postaciach klinicznych jako:

1. postać płucna, nazywana chorobą legionistów, przypominająca ostre zapalenie płuc - stanowi od 3 do $8 \%$ wszystkich legionelloz, cechuje się wysoką śmiertelnością na poziomie od 15 do $20 \%$, a w wypadku zakażeń szpitalnych — od 30 do nawet $80 \%$;

2. postać pozapłucna (gorączka Pontiac) o łagodniejszym przebiegu z objawami grypopodobnymi - stanowi do $90 \%$ przypadków legionelloz, chorzy ulegają samowyleczeniu po kilku dniach, dotychczas nie odnotowano zgonów w wyniku wystąpienia gorączki Pontiac (Matuszewska, Krogulska 2009, s. 57);

3. postać pozapłucna ciężka - występująca niezmiernie rzadko u osób poddawanych immunosupresji lub ze znacznym niedoborem odporności, cechuje się ciężkim przebiegiem klinicznym (Kalicki et al. 2011, s. 417). Szacuje, iż objawy pozapłucne mogą dotyczyć również około jednej trzeciej osób, u których rozwinęła się klasyczna postać płucna legionellozy (Palusińska-Szysz, Cendrowska-Pinkosz 2008, s. 344).

Głównymi czynnikami wpływającymi na prawdopodobieństwo zachorowania są: podeszły wiek, niedobór odporności, przewlekłe choroby układu oddechowego, cukrzyca, nadużywanie papierosów i alkoholu oraz płeć - mężczyźni chorują bowiem nawet trzy razy częściej niż kobiety (Pancer, Stypułkowska-Misiurewicz 2001, s. 63).

Obowiązek (od 2008 roku) badania wody ciepłej pod kątem występowania bakterii Legionella w budynkach zamieszkania zbiorowego, do których zalicza się między innymi hotele, motele, pensjonaty, domy wypoczynkowe, domy wycieczkowe i schroniska młodzieżowe, wprowadzono Rozporządzeniem Ministra Zdrowia z dnia 29 marca 2007 roku w sprawie jakości wody przeznaczonej do spożycia przez ludzi (Dz.U. z 2007 r. Nr 61, poz. 417 z późn. zm.). W rozporządzeniu sprecyzowano miejsca i częstotliwość pobierania próbek wody oraz zależne od wyniku badania dalsze postępowanie. W latach wcześniejszych brakowało przepisów obligujących do przeprowadzania badań. Ustawa z dnia 7 lipca 1994 roku — Prawo budowlane (Dz.U. z 1994 r. Nr 89 poz. 414) oraz Rozporządzenie Ministra Infrastruktury z dnia 12 kwietnia 2002 roku w sprawie warunków technicznych, jakim powinny odpowiadać budynki i ich usytuowanie (Dz.U. z 2002 r. Nr 75, poz. 690 z późn. zm.) dotyczyły tylko kwestii: projektowania, wykonania i eksploatacji instalacji wody ciepłej w taki sposób, aby zapobiegać nadmiernemu rozwojowi bakterii Legionella $s p$.

\section{Cel pracy}

Celem pracy jest ocena częstotliwości występowania pałeczek Legionella sp. oraz poziomu skażenia instalacji ciepłej wody użytkowej obiektów hotelarskich na terenie województwa świętokrzyskiego w latach 2010-2015. 


\section{Materiały i metody}

Materiał do badań stanowiły próbki pobrane w latach 2009-2015 z instalacji wody ciepłej 228 obiektów świadczących usługi hotelarskie na terenie województwa świętokrzyskiego. Obiekty zostały w dalszych analizach podzielone na dwie grupy: hotele oraz pozostałe obiekty, w których świadczone są usługi hotelarskie. Do pozostałych obiektów zaliczono między innymi: motele, pensjonaty, szkolne schroniska młodzieżowe, ośrodki wczasowe, ośrodki szkoleniowo-wypoczynkowe i pokoje gościnne.

Przeszkoleni i upoważnieni pracownicy Państwowej Inspekcji Sanitarnej województwa świętokrzyskiego (11 Powiatowych Stacji Sanitarno-Epidemiologicznych oraz Wojewódzkiej Stacji Sanitarno-Epidemiologicznej w Kielcach) pobierali próbki wytypowane w miejscach wypływu wody ciepłej z urządzeń grzewczych, na końcówkach sieci (w miejscu najdalej położonym od zbiornika wody ciepłej), w punktach pośrednich oraz głównie tam, gdzie z wody ciepłej korzystała duża liczba osób (natryski w łazienkach przy pokojach, natryski w łazienkach ogólnodostępnych). Ogółem pobrano do badań 1414 próbek z 228 obiektów, w tym: 789 próbek z 103 hoteli oraz 625 próbek z 125 pozostałych obiektów, w których świadczone są usługi hotelarskie.

Następnie próbki przebadano metodą filtracji membranowej w Laboratoriach Powiatowych Stacji Sanitarno-Epidemiologicznej w: Busku-Zdroju, Sandomierzu, Skarżysku Kamiennej, Starachowicach, Włoszczowie oraz Wojewódzkiej Stacji Sanitarno-Epidemiologicznej w Kielcach. Oznaczenie pałeczek Legionella przeprowadzono na podstawie metodyki określonej w załączniku nr 9 B Rozporządzenia Ministra Zdrowia z dnia 29 marca 2007 roku w sprawie jakości wody przeznaczonej do spożycia przez ludzi, to jest zgodnie z normą PN-ISO 117312:2008. Otrzymane wyniki poddano analizie i interpretacji, biorąc pod uwagę załącznik nr 7 tego rozporządzenia. W zależności od ilości bakterii Legionella (jtk — jednostek tworzących kolonie) w $100 \mathrm{ml}$ próbki skażenie instalacji wody ciepłej w budynku oceniano jako:

— brak skażenia, skażenie znikome (< 100 jtk),

- skażenie średnie (100-1000 jtk),

— skażenie wysokie (1000-10 000 jtk),

— skażenie bardzo wysokie (> 10000 jtk).

\section{Wyniki badań}

Ogółem jakość wody ciepłej skontrolowano w 228 obiektach. Jak widać na rysunku 1, odsetek obiektów, w których w danym roku pobierano próby do badań, wahał się od 41,2\% w roku 2015 do 58,1\% w 2010 roku. We wszystkich latach częściej badano wodę w hotelach niż w pozostałych obiektach świadczących usłu- 
gi hotelarskie. Największy odsetek hoteli poddano kontroli w latach 2009-2010 (w dwóch pierwszych latach istnienia obowiązku badania wody na obecność bakterii Legionella) oraz w 2012 roku, kiedy w Polsce odbywały się Mistrzostwa Europy w Piłce Nożnej. Bezwzględna liczba obiektów, w których skontrolowano jakość wody ciepłej w poszczególnych latach, utrzymywała się na stałym poziomie. Spadek odsetka obiektów poddawanych kontroli wynikał ze znacznego zwiększenia się liczby podmiotów świadczących usługi hotelarskie na terenie województwa świętokrzyskiego. W latach 2009-2015 liczba hoteli wzrosła z 52 do 98 (o 88\%), a wszystkich obiektów z 136 do 238 (o 75\%). Niski procent skontrolowanych obiektów może wynikać również z faktu, iż zgodnie z załącznikiem nr 7 rozporządzenia Ministra Zdrowia z dnia 29 marca 2007 roku w przypadku, gdy w kolejnych badaniach w odstępach rocznych stwierdza się brak skażenia lub skażenia znikome, następne badanie wykonuje się po trzech latach.

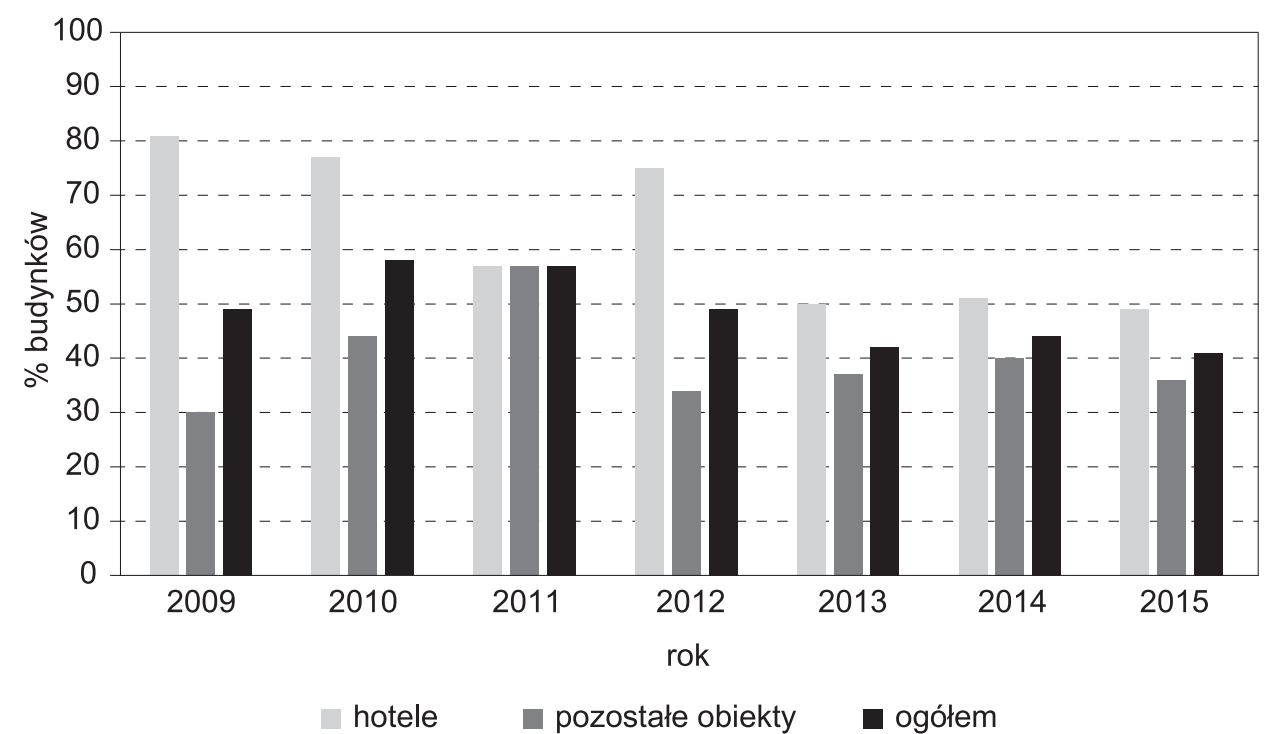

Rysunek 1. Odsetek hoteli oraz pozostałych obiektów, w których w danym roku przeprowadzono badanie wody w kierunku występowania pałeczek Legionella

Źródło: opracowanie własne na podstawie danych Wojewódzkiej Stacji Sanitarno-Epidemiologicznej w Kielcach oraz Banku Danych Lokalnych i GUS.

W latach 2009-2015 skolonizowaną sieć wody ciepłej wykazano w 69 obiektach $(29,2 \%)$ w województwie świętokrzyskim. Niższy odsetek (18\% w 2010 roku oraz 25\% w 2011 roku) skażenia sieci wody ciepłej w hotelach w województwie opolskim opisali w swojej pracy Matejuk, Posmyk i Simon (2012, s. 625). Zgodnie z tabelą 1 ponadnormatywną ilość bakterii Legionella stwierdzono w 19,2\% ogółu pobranych próbek. Podobny poziom skażonych próbek pobranych z hoteli przedstawiają Matejuk et al. (2012, s. 625). Z ich badań wynika, że 15,6\% oraz 
13,4\% próbek (odpowiednio w latach 2010 i 2011) wykazywało przekroczenie dopuszczalnego poziomu bakterii Legionella. Jeszcze niższy odsetek przekroczeń $(10,9 \%)$ stwierdzili Wojtyła-Bucior, Chrzanowska i Marcinkowski (2013, s. 329) w próbkach pobranych $\mathrm{z}$ budynków hoteli w województwie wielkopolskim. Natomiast we włoskich hotelach $21 \%$ pobranych próbek cechowało się skażeniem na poziomie średnim lub wyższym (Bonetta et al. 2009, s. 1578).

Z badań własnych wynika, że 2,1\% próbek zawierało skażenie określone jako wysokie. Otrzymany wynik niewiele odbiega od przedstawionych w pracach Matejuk, Posmyk i Simon (2012, s. 625) oraz Wojtyła-Bucior, Chrzanowska i Marcinkowski (2013, s. 329). W próbkach pobranych z hoteli w województwie opolskim skażenie na poziomie wysokim dotyczyło 1,8\% prób, a w wielkopolskim - 2,8\%. W żadnej próbce pobranej z obiektów hotelarskich w województwie świętokrzyskim bakterie Legionella $s p$. nie występowały w ilości powyżej 10000 jtk/100 ml. Tak wysoki poziom skażenia w Polsce występuje rzadko, co potwierdzają $\mathrm{w}$ swoich pracach wskazani badacze. Bakterie Legionella $\mathrm{w}$ ilości powyżej $10000 \mathrm{jtk} / 100 \mathrm{ml}$ stwierdzono tylko w $0,4 \%$ próbek pobranych $\mathrm{z}$ hoteli w województwie wielopolskim.

Jak wynika z tabeli 1, pomiędzy hotelami a pozostałymi obiektami występuje istotna różnica w odsetku obiektów, w których stwierdzono skażenia mikrobiologiczne sieci. W wypadku hoteli problem ten dotyczył aż 41,7\% obiektów. Ze względu na stwierdzone skażenie na poziomie wysokim w $8,7 \%$ hoteli konieczne było wprowadzenie zakazu korzystania z pryszniców do czasu przeprowadzenia skutecznej dezynfekcji. Maksymalny poziom skażenia, jaki wykazano za pomocą analiz mikrobiologicznych w przypadku hoteli, wynosił 5,6 $\times 10^{3} \mathrm{jtk} / 100 \mathrm{ml}$. W budynkach hoteli ogółem pobrano 789 próbek; skażenia na poziomie średnim stwierdzono $\mathrm{w} 21,8 \%$, a na poziomie wysokim - w $2,8 \%$ poddanych analizie próbek. W pozostałych obiektach świadczących usługi hotelarskie bakterie Legio-

Tabela 1. Występowanie pałeczek Legionella sp. w instalacjach wody ciepłej użytkowej w obiektach hotelarskich na terenie województwa świętokrzyskiego

\begin{tabular}{|c|c|c|c|c|c|c|c|c|}
\hline \multirow{2}{*}{$\begin{array}{l}\text { Rodzaj } \\
\text { obiektu }\end{array}$} & \multirow{2}{*}{$\begin{array}{c}\text { Liczba } \\
\text { budyn- } \\
\text { ków, } \\
\text { w których } \\
\text { pobrano } \\
\text { próbki }\end{array}$} & \multicolumn{3}{|c|}{$\begin{array}{c}\text { Poziom skażenia instalacji } \\
\text { wody ciepłej użytkowej } \\
\text { w budynkach }\end{array}$} & \multirow{2}{*}{$\begin{array}{l}\text { Liczba } \\
\text { pobra- } \\
\text { nych } \\
\text { próbek }\end{array}$} & \multicolumn{3}{|c|}{$\begin{array}{l}\text { Liczb próbek, w których } \\
\text { stwierdzono bakterie Legio- } \\
\text { nella sp. w jtk/100 ml }\end{array}$} \\
\hline & & $\begin{array}{c}\text { brak/ } \\
\text { znikome }\end{array}$ & średnie & wysokie & & $<100$ & $\begin{array}{l}100- \\
1000\end{array}$ & $\begin{array}{l}1000- \\
10000\end{array}$ \\
\hline hotele & 103 & $\begin{array}{c}60 \\
(58,3 \%)\end{array}$ & $\begin{array}{c}34 \\
(33,0 \%)\end{array}$ & $\begin{array}{c}9 \\
(8,7 \%)\end{array}$ & 789 & $\begin{array}{c}595 \\
(75,4 \%)\end{array}$ & $\begin{array}{c}172 \\
(21,8 \%)\end{array}$ & $\begin{array}{c}22 \\
(2,8 \%)\end{array}$ \\
\hline $\begin{array}{l}\text { pozo- } \\
\text { stałe }\end{array}$ & 125 & $\begin{array}{c}99 \\
(79,2 \%)\end{array}$ & $\begin{array}{c}20 \\
(16,0 \%)\end{array}$ & $\begin{array}{c}6 \\
(4,8 \%) \\
\end{array}$ & 625 & $\begin{array}{c}547 \\
(87,5 \%)\end{array}$ & $\begin{array}{c}70 \\
(11,2 \%) \\
\end{array}$ & $\begin{array}{c}8 \\
(1,3 \%) \\
\end{array}$ \\
\hline $\begin{array}{l}\text { OGÓ- } \\
\text { ŁEM }\end{array}$ & 228 & $\begin{array}{c}159 \\
(69,8 \%)\end{array}$ & $\begin{array}{c}54 \\
(23,7 \%)\end{array}$ & $\begin{array}{c}15 \\
(6,5 \%)\end{array}$ & 1414 & $\begin{array}{c}1142 \\
(80,8 \%)\end{array}$ & $\begin{array}{c}242 \\
(17,1 \%)\end{array}$ & $\begin{array}{c}30 \\
(2,1 \%)\end{array}$ \\
\hline
\end{tabular}

Źródło: opracowanie własne na podstawie danych Wojewódzkiej Stacji Sanitarno-Epidemiologicznej w Kielcach. 
nella $\mathrm{w}$ ilości większej niż 100 jtk/100 ml stwierdzono w 20,8\% obiektów, w tym w 4,8\% występowało skażenie wysokie. Również odsetek próbek, w których wykazano przekroczenia, był niższy niż w przypadku hoteli - wynosił $12,5 \%$, czyli prawie o połowę mniej. Najwyższe skażenie, jakie występowało w tej klasie obiektów, wynosiło $2,9 \times 10^{3} \mathrm{jtk} / 100 \mathrm{ml}$.

Badania mikrobiologiczne wody ciepłej w celu wykrycia bakterii Legionella laboratoria Państwowej Inspekcji Sanitarnej przeprowadzają od 2008 roku (w pierwszym roku prowadzenia badań próbki pobierane były głównie z budynków szpitali). Analizując tabele 2 i 3, można zauważyć, że w poszczególnych latach odsetek obiektów oraz pobranych próbek, w których stwierdzono skażenie pałeczkami Legionella, różnił się. W latach 2009-2012 od 23,8\% do 43,6\% instalacji wody ciepłej budynków hoteli uznano za skolonizowane bakteriami Legionella. Szczególną uwagę należy zwrócić na rok 2011, w którym skażenie odnotowano $\mathrm{w} 43,6 \%$ hoteli (w 7,7\% stwierdzono skażenie na poziomie wysokim). W latach 2013-2015 poziom kolonizacji utrzymywał się na stałym poziomie i wynosił 17,1-18,8\%. Odsetek prób pobranych w budynkach hoteli, w których stwierdzono ponadnormatywną ilość bakterii Legionella, w zależności od roku wahał się od $15,4 \%$ do $33,8 \%$.

Tabela 2. Występowanie pałeczek Legionella $s p$. w instalacjach wody ciepłej użytkowej hoteli na terenie województwa świętokrzyskiego

\begin{tabular}{|c|c|c|c|c|c|c|c|c|}
\hline \multirow{2}{*}{ Rok } & \multirow{2}{*}{$\begin{array}{l}\text { Liczba bu- } \\
\text { dynków hote- } \\
\text { li, w których } \\
\text { pobrano } \\
\text { próbki }\end{array}$} & \multicolumn{3}{|c|}{$\begin{array}{c}\text { Poziom skażenia instalacji } \\
\text { wody ciepłej użytkowej } \\
\text { w budynkach }\end{array}$} & \multirow{2}{*}{$\begin{array}{l}\text { Liczba } \\
\text { pobra- } \\
\text { nych } \\
\text { próbek }\end{array}$} & \multicolumn{3}{|c|}{$\begin{array}{c}\text { Liczb próbek, w których } \\
\text { stwierdzono bakterie Legio- } \\
\text { nella sp. w jtk/100 ml }\end{array}$} \\
\hline & & $\begin{array}{c}\text { brak/ } \\
\text { zniko- } \\
\text { me }\end{array}$ & średnie & wysokie & & $<100$ & $\begin{array}{l}100- \\
1000\end{array}$ & $\begin{array}{l}1000- \\
10000\end{array}$ \\
\hline 2009 & 42 & $\begin{array}{c}32 \\
(76,2 \%)\end{array}$ & $\begin{array}{c}9 \\
(21,4 \%)\end{array}$ & $\begin{array}{c}1 \\
(2,4 \%)\end{array}$ & 113 & $\begin{array}{c}86 \\
(76,1 \%)\end{array}$ & $\begin{array}{c}24 \\
(21,2 \%)\end{array}$ & $\begin{array}{c}3 \\
(2,7 \%)\end{array}$ \\
\hline 2010 & 51 & $\begin{array}{c}35 \\
(68,6 \%)\end{array}$ & $\begin{array}{c}14 \\
(27,5 \%)\end{array}$ & $\begin{array}{c}2 \\
(3,9 \%)\end{array}$ & 134 & $\begin{array}{c}99 \\
(73,9 \%)\end{array}$ & $\begin{array}{c}31 \\
(23,1 \%)\end{array}$ & $\begin{array}{c}4 \\
(3,0 \%)\end{array}$ \\
\hline 2011 & 39 & $\begin{array}{c}22 \\
(56,4 \%)\end{array}$ & $\begin{array}{c}14 \\
(35,9 \%)\end{array}$ & $\begin{array}{c}3 \\
(7,7 \%)\end{array}$ & 90 & $\begin{array}{c}61 \\
(67,8 \%)\end{array}$ & $\begin{array}{c}24 \\
(26,7 \%)\end{array}$ & $\begin{array}{c}5 \\
(5,6 \%)\end{array}$ \\
\hline 2012 & 55 & $\begin{array}{c}39 \\
(70,9 \%)\end{array}$ & $\begin{array}{c}16 \\
(29,1 \%)\end{array}$ & $\begin{array}{c}0 \\
(0,0 \%)\end{array}$ & 133 & $\begin{array}{c}88 \\
(66,2 \%)\end{array}$ & $\begin{array}{c}45 \\
(33,8 \%)\end{array}$ & $\begin{array}{c}0 \\
(0,0 \%)\end{array}$ \\
\hline 2013 & 41 & $\begin{array}{c}34 \\
(82,9 \%)\end{array}$ & $\begin{array}{c}6 \\
(14,6 \%)\end{array}$ & $\begin{array}{c}1 \\
(2,4 \%)\end{array}$ & 98 & $\begin{array}{c}79 \\
(80,6 \%)\end{array}$ & $\begin{array}{c}16 \\
(16,3 \%)\end{array}$ & $\begin{array}{c}3 \\
(3,1 \%)\end{array}$ \\
\hline 2014 & 48 & $\begin{array}{c}39 \\
(81,3 \%)\end{array}$ & $\begin{array}{c}8 \\
(16,7 \%)\end{array}$ & $\begin{array}{c}1 \\
(2,1 \%)\end{array}$ & 117 & $\begin{array}{c}94 \\
(80,3 \%)\end{array}$ & $\begin{array}{c}20 \\
(17,1 \%)\end{array}$ & $\begin{array}{c}3 \\
(2,6 \%)\end{array}$ \\
\hline 2015 & 48 & $\begin{array}{c}36 \\
(81,3 \%)\end{array}$ & $\begin{array}{c}6 \\
(12,5 \%)\end{array}$ & $\begin{array}{c}3 \\
(6,3 \%)\end{array}$ & 104 & $\begin{array}{c}88 \\
(84,6 \%)\end{array}$ & $\begin{array}{c}12 \\
(11,5 \%)\end{array}$ & $\begin{array}{c}4 \\
(3,8 \%)\end{array}$ \\
\hline
\end{tabular}

Źródło: opracowanie własne na podstawie danych Wojewódzkiej Stacji Sanitarno-Epidemiologicznej w Kielcach. 
We wszystkich latach prowadzenia badań odsetek pozostałych obiektów, w których stwierdzono kolonizację sieci, był niższy w porównaniu z hotelami. W żadnym roku problem skażenia sieci nie dotyczył więcej niż $20 \%$ obiektów, a w 2013 roku problem występowania bakterii Legionella odnotowano tylko w 8,7\% budynków. Również odsetek próbek pobranych w pozostałych obiektach, zawierających więcej niż 100 jtk/100 ml bakterii Legionella, był niższy w porównaniu z hotelami. W 2013 roku zdyskwalifikowano tylko 6 na 90 pobranych do analizy mikrobiologicznej próbek, co stanowiło 6,7\% ogółu.

Tabela 3. Występowanie pałeczek Legionella sp. w instalacjach wody ciepłej użytkowej pozostałych obiektów świadczących usługi hotelarskie na terenie województwa świętokrzyskiego

\begin{tabular}{|c|c|c|c|c|c|c|c|c|}
\hline \multirow{2}{*}{ Rok } & \multirow{2}{*}{$\begin{array}{c}\text { Liczba bu- } \\
\text { dynków pozo- } \\
\text { stałych obiek- } \\
\text { tów, w któ- } \\
\text { rych pobrano } \\
\text { próbki }\end{array}$} & \multicolumn{3}{|c|}{$\begin{array}{c}\text { Poziom skażenia instalacji } \\
\text { wody ciepłej użytkowej } \\
\text { w budynkach }\end{array}$} & \multirow{2}{*}{$\begin{array}{l}\text { Liczba } \\
\text { pobra- } \\
\text { nych } \\
\text { próbek }\end{array}$} & \multicolumn{3}{|c|}{$\begin{array}{c}\text { Liczb próbek, w których } \\
\text { stwierdzono bakterie Legio } \\
\text { nella sp. w jtk/100 ml }\end{array}$} \\
\hline & & $\begin{array}{c}\text { brak/ } \\
\text { zniko- } \\
\text { me }\end{array}$ & średnie & wysokie & & $<100$ & $\begin{array}{l}100- \\
1000\end{array}$ & $\begin{array}{l}1000- \\
10000\end{array}$ \\
\hline 2009 & 25 & $\begin{array}{c}22 \\
(88,0 \%)\end{array}$ & $\begin{array}{c}3 \\
(12,0 \%)\end{array}$ & $\begin{array}{c}0 \\
(0,0 \%)\end{array}$ & 60 & $\begin{array}{c}49 \\
(81,7 \%)\end{array}$ & $\begin{array}{c}11 \\
(18,3 \%)\end{array}$ & $\begin{array}{c}0 \\
(0,0 \%)\end{array}$ \\
\hline 2010 & 39 & $\begin{array}{c}33 \\
(84,6 \%)\end{array}$ & $\begin{array}{c}5 \\
(12,8 \%)\end{array}$ & $\begin{array}{c}1 \\
(2,6 \%)\end{array}$ & 82 & $\begin{array}{c}71 \\
(86,6 \%)\end{array}$ & $\begin{array}{c}10 \\
(12,2 \%)\end{array}$ & $\begin{array}{c}1 \\
(1,2 \%)\end{array}$ \\
\hline 2011 & 51 & $\begin{array}{c}42 \\
(82,4 \%)\end{array}$ & $\begin{array}{c}8 \\
(15,7 \%)\end{array}$ & $\begin{array}{c}1 \\
(2,0 \%)\end{array}$ & 99 & $\begin{array}{c}84 \\
(84,8 \%)\end{array}$ & $\begin{array}{c}14 \\
(14,1 \%)\end{array}$ & $\begin{array}{c}1 \\
(1,0 \%)\end{array}$ \\
\hline 2012 & 42 & $\begin{array}{c}36 \\
(85,7 \%) \\
\end{array}$ & $\begin{array}{c}5 \\
(11,9 \%)\end{array}$ & $\begin{array}{c}1 \\
(2,4 \%)\end{array}$ & 85 & $\begin{array}{c}75 \\
(88,2 \%)\end{array}$ & $\begin{array}{c}9 \\
(10,6 \%)\end{array}$ & $\begin{array}{c}1 \\
(1,2 \%) \\
\end{array}$ \\
\hline 2013 & 46 & $\begin{array}{c}42 \\
(91,3 \%)\end{array}$ & $\begin{array}{c}4 \\
(8,7 \%)\end{array}$ & $\begin{array}{c}0 \\
(0,0 \%)\end{array}$ & 90 & $\begin{array}{c}84 \\
(93,3 \%)\end{array}$ & $\begin{array}{c}6 \\
(6,7 \%)\end{array}$ & $\begin{array}{c}0 \\
(0,0 \%)\end{array}$ \\
\hline 2014 & 51 & $\begin{array}{c}42 \\
(82,4 \%)\end{array}$ & $\begin{array}{c}5 \\
(9,8 \%) \\
\end{array}$ & $\begin{array}{c}4 \\
(7,8 \%) \\
\end{array}$ & 114 & $\begin{array}{c}98 \\
(86,0 \%) \\
\end{array}$ & $\begin{array}{c}11 \\
(9,6 \%)\end{array}$ & $\begin{array}{c}5 \\
(4,4 \%) \\
\end{array}$ \\
\hline 2015 & 50 & $\begin{array}{c}44 \\
(88,0 \%)\end{array}$ & $\begin{array}{c}6 \\
(12,0 \%)\end{array}$ & $\begin{array}{c}0 \\
(0,0 \%)\end{array}$ & 95 & $\begin{array}{c}86 \\
(90,5 \%)\end{array}$ & $\begin{array}{c}9 \\
(9,5 \%)\end{array}$ & $\begin{array}{c}0 \\
(0,0 \%)\end{array}$ \\
\hline
\end{tabular}

Źródło: opracowanie własne na podstawie danych Wojewódzkiej Stacji Sanitarno-Epidemiologicznej w Kielcach.

Problem występowania pałeczek Legionella dotyczył 43 hoteli i 26 pozostałych obiektów. W wypadku 25 hoteli oraz 9 pozostałych obiektów skażenia instalacji wody ciepłej zostało stwierdzone więcej niż w jednym roku (zob. rysunek 2). W 2 hotelach skażenie sieci występowało w 5 z 7 lat, w których prowadzono badania. Wielokrotne skażenie częściej dotyczyło hoteli niż pozostałych obiektów. Może to być spowodowane bardziej skomplikowaną strukturą instalacji wodociągowej hoteli, co utrudnia zapewnienie w punktach czerpalnych wody o temperaturze $55-60^{\circ} \mathrm{C}$, hamującej namnażanie się bakterii Legionella. 


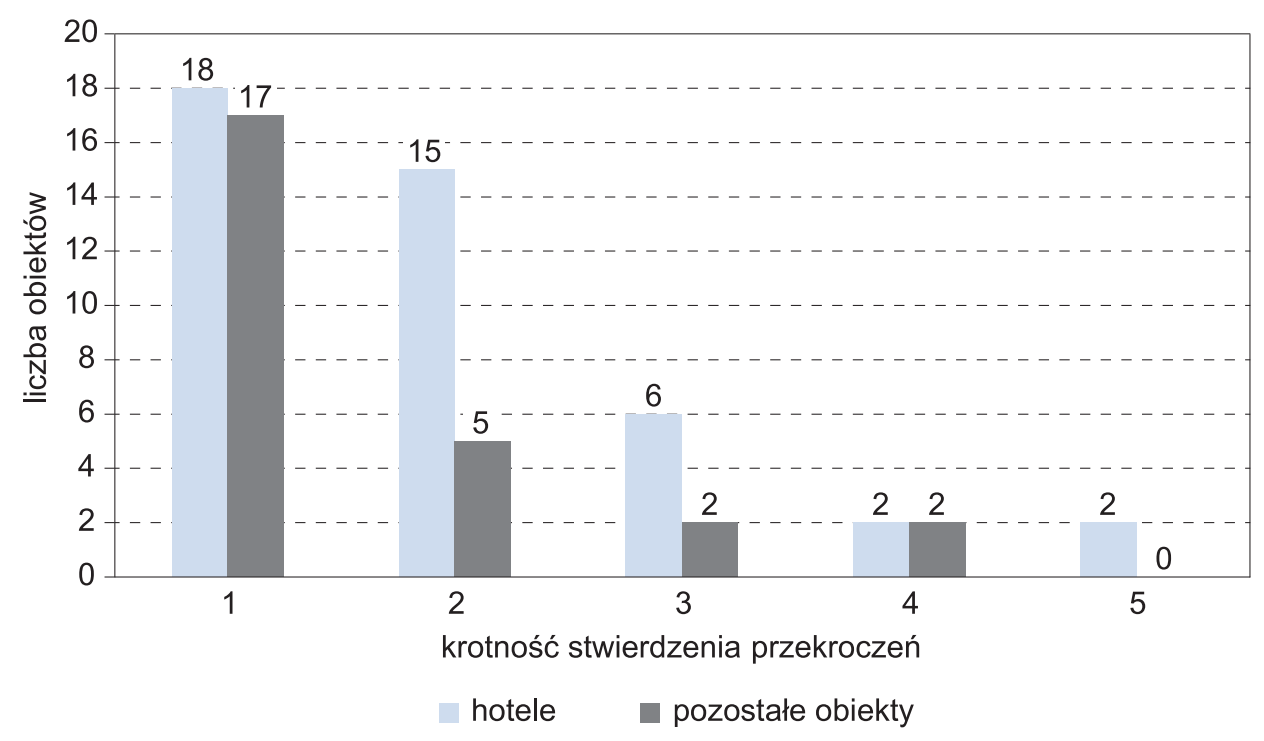

Rysunek 2. Krotność stwierdzenia ponadnormatywnej ilości bakterii Legionella sp. w obiektach hotelarskich w latach 2009-2015

Źródło: opracowanie własne na podstawie danych Wojewódzkiej Stacji Sanitarno-Epidemiologicznej w Kielcach.

\section{Wnioski}

Wyniki przeprowadzonych badań świadczą o powszechności kolonizacji przez bakterie Legionella sp. instalacji wody ciepłej obiektów świadczących usługi hotelarskie na terenie województwa świętokrzyskiego.

1. Problem kolonizacji częściej dotyczył budynków hoteli $(41,2 \%)$ niż pozostałych obiektów, w których są świadczone usługi hotelarskie (20,8\%).

2. W latach 2009-2015 w żadnym obiekcie nie odnotowano skażenia na poziomie bardzo wysokim.

3. Nadal zmniejsza się procent obiektów, w których przeprowadzane są badania wody ciepłej.

4. Przeprowadzanie systematycznego poboru próbek wody w obiektach hotelarskich, w ramach nadzoru sanitarnego, przyczyniło się do spadku liczby obiektów, w których stwierdza się ponadnormatywną ilość bakterii Legionella. Poprawa nie jest jednak tak dobrze widoczna jak w wypadku szpitali, gdzie odsetek budynków ze skolonizowaną siecią spadł z 35,4\% w roku 2009 do 12,6\% w 2015 roku (Szczepanek 2016, s. 248).

5. Za niepokojące należy uznać wielokrotne stwierdzanie przekroczeń w tych samych obiektach. 
6. Pomimo powszechnego występowania bakterii Legionella w analizowanych latach na terenie województwa świętokrzyskiego zgłoszono tylko 3 przypadki legionellozy. Tak mała liczba zachorowań może świadczyć o braku właściwego rozpoznania oraz niezgłaszaniu pojedynczych zachorowań. W Europie notuje się średnio (dane za 2014 rok) 13,5 przypadków zachorowań na 1 mln mieszkańców rocznie (ECDPC 2016, s. 6).

\section{Bibliografia}

Bonetta S. et al. (2009), Evaluation of Legionella pneumophila contamination in Italian hotel water systems by quantitative real-time PCR and culture methods, „Journal of Applied Microbiology" 108, nr 5, s. 1576-1583.

European Centre for Disease Prevention and Control (ECDPC) (2016), Legionnaires' disease in Europe, 2014, Stockholm.

Fields B.S., Benson R.F., Besser R.E. (2002), Legionella and Legionnaires' disease: 25 years of investigation, „Clinical Microbiology Reviews” 15, nr 3, s. 506-526.

Kalicki B. et al. (2011), Zakażenia pałeczkami legionella pneumophila - opis przypadku, „Pediatria i Medycyna Rodzina" 7, nr 4, s. 415-419.

Krogulska B. et al. (2014), Występowanie bakterii z rodzaju Legionella $w$ wodzie technologicznej oraz badania ogólnej liczby bakterii i grzybów w powietrzu na stanowiskach pracy, na których generowany jest aerozol wodny, „Medycyna Praktyczna” 65, nr 3, s. 325-334.

Matejuk A., Posmyk W., Simon K. (2012), Występowanie pałeczek Legionella sp. w instalacjach wodnych obiektów użyteczności publicznej w województwie opolskim w latach 2010-2011, „Przegląd Epidemiologiczny” 66, s. 623-628.

Matuszewska R., Krogulska B. (2009), Problem występowania pałeczek Legionella w instalacjach i urzadzeniach wytwarzajacych aerozol wodno-powietrzny w obiektach stużby zdrowia w Polsce, „Nowa Medycyna” 1, s. 56-60.

Palusińska-Szysz M., Cendrowska-Pinkosz M. (2008), Wystęowanie i chorobotwórczość bakterii z rodziny Legionellaceae, „Postępy Higieny i Medycyny Doświadczalnej” 62, s. 337-353.

Pancer K., Stypułkowska-Misiurewicz H. (2009), Epidemiologia zachorowań wywołanych przez Legionella sp., „Nowa Medycyna” 1, s. 61-65.

Rozporządzenie Ministra Infrastruktury z dnia 12 kwietnia 2002 roku w sprawie warunków technicznych, jakim powinny odpowiadać budynki i ich usytuowanie (Dz.U. z 2002 r. Nr 75, poz. 690 z późn. zm.).

Rozporządzenie Ministra Zdrowia z dnia 29 marca 2007 roku w sprawie jakości wody przeznaczonej do spożycia przez ludzi (Dz.U. z 2007 r. Nr 61, poz. 417 z późn. zm.).

Stojek N. (2004), Zagrożenie bakteriami z rodzaju Legionella w środowisku pracy, „Podstawy i Metody Oceny Środowiska Pracy" 3 (41), s. 61-67.

Szczepanek A. (2016), Występowanie pałeczek Legionella sp. w instalacjach ciepłej wody użytkowej w budynkach użyteczności publicznej z terenu województwa świętokrzyskiego, [w:] Człowiek a środowiska - wzajemne oddziaływania, red. J. Chmielewski, I. Żeber-Dzikowska, B. Gworek, Warszawa, s. 239-249.

Ustawa z dnia 7 lipca 1994 roku — Prawo budowlane (Dz.U. z 1994 r. Nr 89 poz. 414).

Wojtyła-Buciora P., Chrzanowska E., Marcinkowski J. (2013), Występowanie pałeczek Legionella sp. w instalacjach wody użytkowej w zakladach opieki zdrowotnej oraz budynkach użyteczności publicznej, „Hygeia. Public Health” 48, nr 3, s. 327-332.

World Health Organization (WHO) (2011), Guidelines for Drinking-Water Quality, wyd. 4, Geneva.

Ekonomia — Wroclaw Economic Review 23/4 (2017)

(C) for this edition by CNS 